\title{
RELAÇÕES ENTRE O INSÓLITO E OS LEITORES EMPÍRICO E VIRTUAL
}

Shirley de Souza Gomes CARREIRA19

\section{Introdução}

Discorrer sobre o insólito na literatura exige uma reflexão prévia sobre três conceitos abordados por Tzvetan Todorov: o estranho, o maravilhoso e o fantástico.

Segundo Todorov, o gênero maravilhoso constitui o sobrenatural aceito:

os elementos sobrenaturais não provocam qualquer reação particular nem nas personagens, nem no leitor implícito. Não é uma atitude para com os acontecimentos narrados que caracteriza o maravilhoso, mas a própria natureza desses acontecimentos. (TODOROV: 1975, p.60)

O gênero estranho caracteriza-se como o sobrenatural explicado, isto é, refere-se a "acontecimentos que podem perfeitamente ser explicados pelas leis da razão, mas que são, de uma maneira ou de outra, incríveis, extraordinários, chocantes, singulares, inquietantes, insólitos" e que, por esta razão, provocam na personagem e no leitor reação semelhante àquela produzida pelos textos fantásticos (TODOROV:1975, p.53).

Cabe ao fantástico a característica de se localizar no limite dos dois outros gêneros, ocorrendo em circunstâncias permeadas de incertezas: "O fantástico é a hesitação experimentada por um ser que só conhece as leis naturais, face um acontecimento aparentemente sobrenatural" (TODOROV: 1975, p.31).

Ainda segundo Todorov, o fantástico exige uma integração do leitor no mundo das personagens, uma vez que se define pela percepção ambígua que o próprio leitor tem dos acontecimentos narrados (TODOROV: 1975, p.37). No entanto, o leitor mencionado por Todorov não é o leitor empírico, mas uma "função" de leitor implícita no texto. Esse leitor implícito detém as características de um leitor potencial, idealizado, materializando um conjunto de orientações que há de guiar o possível leitor empírico no sentido de uma interpretação adequada da obra, segundo a ótica de seu autor. A hesitação, a ambigüidade suscitada pelo fantástico só é possível mediante a existência desse leitor implícito.

${ }^{19}$ Doutora em Literatura Comparada pela UFRJ. 
Se em dado momento a literatura fantástica surgiu de forma a dar uma roupagem nova à abordagem de determinados assuntos que até então constituíam tabu para a sociedade, o advento da psicanálise tratou de desvelar os temas ocultos, dando um golpe mortal no fantástico em sua concepção tradicional, dando origem a uma concepção moderna.

O Realismo Maravilhoso, surgido no século XX, é um gênero que se preocupa com a gênese de uma nova visão da realidade expressa por um experimentalismo narrativo que enseja a construção de uma imagem plurissignificante do real.

O termo "insólito" corresponde ao que é anormal, incomum, extraordinário. Vai além dos conceitos de realidade, verdade e até mesmo de gênero literário, pois sua presença na narrativa envolve efeitos diferentes, dependendo da época. No mundo contemporâneo, em que a verdade absoluta já foi contestada e as fronteiras entre o real e o irreal apresentam-se diluídas nas narrativas, há que repensar o papel do insólito nos textos ficcionais, bem como rever a sua relação com os leitores empíricos e virtuais.

\section{A teoria em busca do perfil do leitor}

Quando, em sua aula inaugural na Universidade de Constança, em 1967, Hans Jauss deixou explícita a necessidade de distinguir dois processos diferentes de recepção de uma obra literária, ou seja, o significado para o leitor contemporâneo e o processo histórico pelo qual o texto é recebido e interpretado pelos leitores diversos, ele lançou as bases do que se convencionou chamar de "Estética da recepção".

A tentativa de delimitar o campo de ação do leitor empírico deu origens a diversas teorias da recepção, bem como fez que com que surgissem vários tipos de nomenclaturas com foco no receptor:

Nas últimas décadas impôs-se uma mudança de paradigma em relação às discussões críticas precedentes. Se em clima estruturalista privilegiava-se a análise do texto como objeto dotado de caracteres estruturais próprios, passíveis de serem descritos através de um formalismo mais ou menos rigoroso, em seguida a discussão passou a ser orientada para uma pragmática da leitura. Do início dos anos sessenta em diante, multiplicaramse, assim, as teorias sobre o par Leitor-Autor, e hoje temos, [...] leitores virtuais, leitores ideais, leitores-modelo, superleitores, leitores projetados, leitores informados, arquileitores, leitores implícitos, metaleitores e assim por diante. (ECO: 1999, p. 1) 
Em síntese, independentemente da nomenclatura usada, a leitura constrói um espaço entre o real e o imaginário cujo sentido cabe ao leitor preencher.

Em sua aula, Jauss chamou atenção para a relação dialógica entre leitores e obra, afirmando que as atualizações são regidas pelo horizonte de expectativas, tanto da obra quanto dos leitores. Para ele, a reconstrução desse horizonte de expectativas social era o elemento mais complicado no exame analítico das obras literárias, uma vez que o horizonte de expectativas internas à obra era derivável do próprio texto e, portanto, menos problemático.

A experiência estética por ele descrita se caracterizaria pela fruição da obra em três planos distintos, porém simultâneos e complementares: o da consciência como atividade produtora (poiesis), o da consciência como atividade receptora (aisthesis) e o plano da reflexão que se identifica com a ação (katharsis).

As reflexões de Jauss encontravam eco na teoria do efeito estético proposta por Wolfgang Iser, que tinha como base fundamental a noção de leitor-implícito, que já indicava as marcas que o texto carregava, supondo informações, repertório e valores comuns.

Para Iser, o leitor constrói o significado a partir de indeterminações, experimentando no ato interpretativo um efeito estético, em decorrência de sua interação com a obra, transformando o significado (o enunciado da estrutura) em significação (o que o leitor constrói).

A partir dos anos 60, intensificando-se nos anos 70 do século $\mathrm{XX}$, as correntes voltadas para o estudo da literatura começaram a assumir denominações que aludiam ao leitor.

Em Opera Aperta (1962), Umberto Eco afirma que a cultura é um sistema de signos, que merece ser interpretada por um arquétipo de leitor, capaz de conhecer de modo ideal os princípios da semiose ilimitada.

Mais tarde, em Lector infabula (1979), The role of the reader (1979), Os limites da interpretação (1995), Interpretação e superinterpretação (1997) e em Seis passeios pelos bosques da recepção (1994), o próprio Eco desconstrói o princípio da obra aberta, afirmando que a obra literária exige um equilíbrio entre a infinidade de interpretações que pode gerar e uma hermenêutica normativa, em que os papéis do autor e do receptor são fundamentais. Ele tenta comprovar a existência de uma intentio operis, interpretada como uma estratégia semiótica, decorrente da leitura. Para Eco, a interpretação feita 
pelo receptor está implícita no próprio texto, uma vez que a "intenção do texto" é a de produzir um leitor - modelo capaz de fazer conjeturas sobre ele. A iniciativa do leitor consiste em imaginar um autor-modelo, que não corresponde ao autor empírico, que, no fim, coincide com a intenção do texto. A intentio operis, ao contrário do que se pode supor, não restringe totalmente o leque de interpretações possíveis, mas, por outro lado, impede que se veja a interpretação de uma obra como algo infinito.

O papel do leitor como "decodificador" do texto tem uma relação intrínseca com a interpretação do insólito no universo ficcional.

Em Otras Inquisiciónes, Jorge Luis Borges reporta-se à criação do poema "Kublai Khan", de Samuel Coleridge, para teorizar sobre uma zona de confluência entre o real e o imaginário, entre a ficção e a realidade e entre os gêneros.

Quando Coleridge e Wordsworth delimitaram o campo de seu fazer poético na produção de Lyrical Ballads, primeira obra romântica em língua inglesa, a Coleridge coube a tarefa de transformar o sobrenatural, o insólito, em algo crível. Para tanto, o leitor deveria ler seus poemas a partir da "suspensão voluntária da descrença", uma espécie de pacto a ser estabelecido entre o leitor e o texto.

A aceitação do pacto, ou quid pro quo, dar-se-ía a partir da identificação do leitor empírico com o leitor potencial da obra, aquele que fora idealizado pelo autor quando da sua escrita, em suma: o leitor capaz de compreendê-la em sua amplitude e em seus mais profundos e ocultos significados. A suspensão da descrença estaria, pois, associada à aceitação natural do que em outras circunstâncias poderia ser interpretado como algo sobrenatural, causador de estranhamento, ou seja, à naturalização do insólito.

Essa reflexão prévia sobre os perfis de leitores encontrará exemplificação em $O$ outro pé da sereia, de Mia Couto, que analisaremos tendo como contraponto outras obras da literatura dos séculos XX e XXI.

\section{As faces do insólito em $O$ outro pé da sereia, de Mia Couto}

A questão do que pode ser ou não considerado insólito tem ocupado os investigadores da área, principalmente, quando essas manifestações se apresentam em obras que têm como background culturas não-ocidentais, como é o caso da África e do Oriente Médio. 
Ao examinarmos o insólito na obra de Mia Couto incorremos no risco de ouvir que no contexto em que sua obra se insere o insólito não existe, uma vez que o sobrenatural e o maravilhoso já fazem parte da cultura africana.

Uma afirmação como essa soa bem mais restrita quanto à possibilidade de interpretação do que o conceito de intentio operis de Eco, uma vez que pressupõe um leitor-modelo africano, ou versado na cultura africana, que veja o texto apenas com um reflexo da cultura que o produziu.

Por mais que um texto postule seu leitor-modelo, ele é lido por leitores empíricos, independentemente de localização geográfica ou etnia e, além disso, a obra de Mia Couto tem um escopo "extramuros", que ultrapassa os limites do continente africano.

Em O outro pé da sereia, Mia Couto arquiteta o texto com a estrutura de uma metaficção historiográfica, com duas narrativas temporalmente distanciadas, porém narradas alternadamente, de modo a iluminarem-se mutuamente.

Em ambas as narrativas o insólito se faz presente, ora naturalizado no universo ficcional ora produzindo estranheza até mesmo nas personagens.

O romance dialoga com outras obras, notadamente com Cem anos de solidão, de Gabriel Garcia Márquez, do qual toma por empréstimo a atmosfera onírica que permeia o discurso e o traço de algumas personagens, como Melquíades, o cigano. No entanto, pode-se observar que, ao contrário do romance de Garcia Márquez, em que o insólito surge de uma forma banalizada, aceita incondicionalmente por todas as personagens, a obra de Mia Couto explora o insólito em suas múltiplas faces.

Ao inserir dados históricos em seu texto, incontestavelmente, cria um leitormodelo, capaz de recuperar o intertexto traçando analogias com a história do presente que também está a contar.

Segundo Silva Rego (1971, 296-297), a história missionária moçambicana principia com a expedição dos Padres Gonçalo da Silveira e André Fernandes e do Irmão André da Costa, que fora enviada em 1560 pelo Vice-Rei da Índia, D. Constantino de Bragança, com a finalidade de conversão do Monomotapa. Em 1563, Pio IV cria a Administração Eclesiástica de Moçambique e Sofala.

A atuação missionária da Igreja Católica nas terras em que os Portugueses chegaram com a sua cultura esteve sempre relacionada com as atividades políticas, 
econômicas, sociais e religiosas da Metrópole. Estas acabavam por ter o seu reflexo nos territórios e povos que a Santa Sé confiara a Portugal para evangelizar.

Moçambique pertencia ao Bispado de Goa, desmembrado do Bispado do Funchal em 1534, quando Paulo III, através da Bula Aequum Reputamus, cria aquela nova Diocese. Este novo Bispado compreendia toda a extensão territorial desde o Cabo da Boa Esperança até ao Japão.

Com base nesse contexto histórico, Mia Couto tece uma narrativa histórica, que conta como a referida imagem de Nossa Senhora chegou a Moçambique, trazida pelo jesuíta D. Gonçalo da Silveira em uma nau portuguesa em 1560. A imagem, benzida pelo papa, era destinada ao imperador do mítico reino de Monomotapa, a fim de catequizar a região.

O relato da viagem é uma das duas histórias paralelas que o romance narra, que contém o elo que se estabelece com a narrativa do presente.

Em um primeiro momento pode-se dizer que do leitor-modelo desse romance exigir-se-á o discernimento para, a partir do que o romance narra em seus dois níveis distintos, passado e presente, recuperar aspectos contextuais que levem à compreensão da obra como um todo.

Além do evidente diálogo com a historiografia, o romance apresenta elementos do Realismo Mágico latino-americano.

No nível da narrativa histórica, o insólito está associado à crise de identidade e ao choque entre culturas, que as formas diferenciadas de devoção à imagem da Virgem emblematizam.

Ao ver a imagem da santa tombar no lodo, durante o carregamento da nau, o escravo Nimi Nsundi se atira às águas, evitando que fosse tragada. Mais tarde, ao ver D. Gonçalo da Silveira limpando os pés da santa, diz que ela não havia escorregado; que ela queria ficar ali, no pântano. A devoção do escravo à Santa comove o missionário, incapaz de compreender a quem Nsundi realmente cultuava.

Em quimbundo, as sereias são chamadas de "ianda", no singular "kianda". As águas têm significado especial nas manifestações culturais africanas por remeterem aos mitos de fundação que regem as múltiplas formas de vida.

No romance, o escravo Nsundi envia entrega a Dia Kumari uma carta, na qual relata que, quando se ajoelha diante da Virgem, ele presta culto a Kianda: 
Critica-me porque aceitei lavar-me dos meus pecados. Os portugueses chamam isso de baptismo. Eu chamo de outra maneira. Eu digo que estou entrando em casa de Kianda.A sereia, deusa das águas. É essa deusa que me escuta quando me ajoelho perante o altar da Virgem. (...) Acontecia-me a mim o inverso do que lhe sucedeu a si, Dia Kumari. As minhas mãos se juntavam e pegavam fogo. Em lugar de dedos me ardiam dez pequenas labaredas. Era então que outras mãos, feitas de água, se aconchegavam nas minhas e aplacavam aquela fogueira. Essas mãos eram da Santa. E ela me segredava: - Este é o tempo da água. Era a voz da Santa que me percorria por dentro. A voz tomava posse de mim. E agora que lhe escrevi a carta, vejo que esta letra não me pertence, é letra de mulher. Meus pulsos delgados se recolhem ao peso de um cansaço de séculos. Meus dedos não têm gesto, meus dedos são o próprio gesto. Eu sou a Santa. (COUTO, 2006, p.114)

O insólito não surge apenas como manifestação da crença, mas também pela dissolução da fé mediante o reconhecimento da disparidade entre os princípios disseminados pelos religiosos e a sua prática.

Assim como o escravo, Padre Antunes, que acompanha D. Gonçalo em sua missão, experimenta um contato com a santa que é inconcebível segundo a visão cristã. Sonha com uma mulher despedindo-se dele na berna do rio Mandovi. Ela começa a desvencilhar-se de suas roupas, dizendo-lhe que é deste modo que ele há de lembrar-se dela. Angustiado, o padre acorda e, ao dormir novamente, torna a sonhar com a mulher, que lhe diz para tocá-la, pois ela o fará renascer. No sonho, ele afunda, para ser devolvido à tona pela estranha mulher, que, finalmente, se apresenta como Kianda, embora ainda personificando Nossa Senhora. O sonho é o início de uma crise religiosa e identitária

Padre Antunes decidira ser padre por conta de um amor proibido e abdica da batina por perceber-se um homem diferente, após o contato com os africanos e a paixão súbita pela indiana Dia, também passageira da nau Nossa Senhora da Ajuda. Os indícios dessa mudança espalham-se pelo romance antes de sua enunciação final, como comprova esta passagem: "Foi então que reparou que estava com as mãos sujas de tinta. Com as mãos negras, ele reentrou no camarote. E com as mãos negras ele se abandonou no rio do sonho" (COUTO, 2006, p.62). Assim é que Padre Antunes, desiludido com as obviedades de um cristianismo parcial, começa a sofrer uma mutação de raça:

Até 4 de janeiro, data do embarque em Goa, ele era branco, filho e neto de portugueses. No dia 5 de janeiro, começara a ficar 
negro. Depois de apagar um pequeno incêndio em seu camarote, contemplou as suas mãos obscurecendo. Mas agora era a pele inteira que lhe escurecia, os seus cabelos se encrespavam. Não lhe restava dúvida: ele se convertia num negro.

- Estou transitando de raça, D. Gonçalo. E o pior é que estou gostando mais dessa travessia do que de toda a restante viagem. (COUTO, 2006, p.164)

Essas duas passagens do romance evocam experiências idênticas de personagens que se encontram no plano da narrativa no presente.

Desde o primeiro capítulo, a relação entre Mwadia e Zero delineia-se atípica aos olhos do leitor. Ela vive com um homem cuja fala se tornara tão episódica "como se ele estivesse existindo por conta de um outro que já vivera"(p.14). Num certo dia, Zero encontra algo que ele descreve como uma estrela que havia caído do céu e, inclusive, queimara-lhe as mãos ao enterrá-la em seu quintal. A suposta estrela nada mais é que uma aeronave em missão de reconhecimento e espionagem que, aos olhos do pastor de animais, assumira a forma daquilo que mais se assemelhava à bola de fogo em que se tornara.

Após uma conversa com a mulher, ambos decidem desenterrar a estrela e levá-la para ser enterrada junto ao rio, no lugar do bosque sagrado. Mwadia sabe aquilo não é uma estrela, mas os restos do que ela chama de "desembarcação". No entanto, não deseja desmentir o marido. Naquela noite, Zero sonha que suas mãos se juntavam como duas chamas numa única fogueira, que, em lugar dos dedos, lhe doíam dez pequenas labaredas, até que mãos feitas de água se aproximaram das dele, aplacando a sua dor. Como sonâmbulo, ele repete as palavras da mulher que lhe aparece no sonho.

O insólito da situação se institui, portanto, a partir da duplicação, no plano do mundo contemporâneo, de algo acontecido no plano da ficção histórica.

Após enterrar "a estrela", Zero descobre a estátua da Virgem, bem como os pertences de Gonçalo da Silveira, que com ela estavam enterrados, e reconhece nela a mulher do sonho. Decidem levar o achado até o adivinho Lázaro Vivo e decidir o que fazer com ele. O adivinho afirma que Zero despertara a alma do morto, pois uma pessoa assassinada não descansa como os mortos naturais; vira um gnozi. Para que não haja conseqüências sérias, a estátua deve ser levada para Vila Longe. Dada a impossibilidade, até então não explicada, de Zero voltar ao local, fica decidido que Mwadia há de fazê-lo. 
Depois de pedir ao curandeiro que cuide de Zero, ela parte e Lázaro Vivo se pergunta:

(...) saberia a filha de Constança o que a esperava em Vila Longe? Ou recorria à mesma ilusão que produz com os panos pendurados à porta de sua casa: inventaria vidas para preencher o vazio do seu coração natal? (p.47)

Assim como Melquíades, em Cem anos de solidão, o adivinho Lázaro Vivo tem, no universo ficcional, o estatuto do detentor do conhecimento, evocando o seu parentesco com os velhos xamãs, os sacerdotes conhecedores dos mitos, detentores de poderes ocultos e capazes de comunicar-se com os espíritos.

Ao mesmo tempo em que corrobora a aura mágica em torno da personagem, Mia Couto a desconstrói, ao relatar a surpresa de Mwadía ante a "nova versão" do nyanga, que já não portava mais as longas tranças de antes, nem as costumeiras roupas pretas. Ao invés do traje previsível, ele se apresenta, de cabelo curto e penteado de risca, usando uma blusa esportiva, e portando um celular. Lázaro vinha de Vila Longe, onde fora buscar uma tabuleta para pôr na porta de seu "estabelecimento".

O modo com que o autor configura a personagem é uma visão irônica da prontidão em que a África se atira em direção à idéia de globalização, pois o adivinho anuncia logo aos recém-chegados: “- Eu já estou no futuro. Quando chegar aqui a rede, já posso ser contactado para serviços internacionais. Entendem, meus amigos?" (COUTO, 2006, p.24).

O leitor é, portanto, desafiado a uma leitura subliminar do insólito, construída sobre aspectos paradoxais.

Em uma entrevista concedida a Celina Martins (2002), Mia Couto expôs a sua visão sobre o choque de culturas em África:

Esse encontro de culturas é sempre, em princípio, traumático, porque não se trata de um encontro, é uma incursão abusiva. $\mathrm{O}$ que chega a estas culturas africanas não são as culturas européias. São emanações, representações simbólicas por via da tecnologia. Mantemos ainda a imagem dos primeiros encontros dos descobridores europeus que trocavam umas bugigangas que reluziam diante dos olhos dos africanos. Estamos mais ou menos repetindo esse modelo de relação. Não existe globalização, o que existe é exportação e imposição de sinais, nem sequer são modelos, o modelo fica junto do produtor, os africanos consomem passivamente aqueles sinais mais brilhantes $\mathrm{e}$ apelativos. 
Nesse sentido, Lázaro personifica, no mundo contemporâneo, e no âmbito do consumo, a repetição de uma relação de dominação que se oculta sob a égide da globalização. É um homem dividido entre as suas crenças e os possíveis benefícios da tecnologia e da modernidade. O texto deixa entrever, no entanto, que seus poderes são reais. É através de Lázaro que o romance introduz pela primeira vez os rumores acerca da morte de Zero.

A presença de Zero no romance é cercada de incógnitas que se espalham por toda a narrativa, como a convocar o leitor a montar o quebra-cabeça. Ele é um personagem silencioso, descrito como um homem que está "a esquecer-se" (p.14):

Comovia-a, sim, o simples fato de Zero Madzero falar. Desde há anos que a sua voz se tornara tão episódica como se ele estivesse existindo por conta de um outro que já vivera. O homem calava cobras e lagartos. No silêncio, Zero se embalava feito um pêndulo, pontual para lá e para cá.

- Estou a esquecer-me. (p.14)

Ao ler o primeiro capítulo, o leitor estranhará, com certeza, o fato de que Zero, ao ser banhado pela mulher, impregna a água de sangue, mas não se daráconta de imediato que o silêncio dele é o silêncio dos mortos, apesar dos muitos indícios que autor espalha ao longo texto, a começar pela epígrafe do primeiro capítulo:

Em todo mundo é assim: morrem as pessoas, fica a História Aqui, é o inverso: morre apenas a História, os mortos não se vão O Barbeiro de Vila Longe

Depois de consultarem o curandeiro, por exemplo, Mwadia caminha atrás do marido e do burro Mbongolo, como em um cortejo fúnebre, e se assusta, pois lhe parece que o marido não deixa pegadas atrás de si. Chama-o, para ouvir a sua voz, para ter certeza de sua existência. Essa é uma das instâncias de hesitação da personagem.

Em Vila Longe, as demandas do mundo moderno se misturam ao maravilhoso. Os acontecimentos que se seguem à chegada dos americanos se reportam à preocupação do autor com algumas questões que lhe parecem cruciais, como, por exemplo, um desfraldar de bandeiras apoiado na questão da negritude, na busca de uma África mítica, que, de certa forma, ignora a realidade da Moçambique contemporânea, fruto de uma 
intensa miscigenação. Por outro lado, há uma atmosfera onírica que permeia a narrativa, bem marcada pela presença do insólito.

Assim como em Macondo, o insólito é incorporado ao quotidiano das personagens. A citação de João Guimarães Rosa, que serve de epígrafe ao livro, remete à atmosfera onírica que circunda as personagens: "Desde que em alguma outra parte é que vivemos e aqui é só uma nossa experiência de sonho".

Os mortos de Vila Longe faleciam "como era devido naquele lugar: sem nunca chegar a morrer" (COUTO, 2006, p.77). "Almas acesas, brilhando entre sombras, suspiros e silêncios", eles pairavam entre os vivos, dando-se o luxo de envelhecer nas fotografias.

À Mwadia cabe a tarefa de pendurar a última fotografia da tia que falecera na "parede dos ausentes"; no corredor, onde todos os defuntos da família estavam reunidos, em um tipo de memorial mórbido. Estranhamente, na casa de uma família "que nunca chora", um balde é posto junto à parede, para recolher as lágrimas dos mortos (COUTO, 2006, p.74).

A outra epígrafe ao romance, retirada do poema "Ancestralidade", do poeta senegalês Birago Diop, também antecipa a atmosfera criada pelo insólito: "Os mortos/ não morreram. /Eles escutam/ os vivos e as coisas/ Eles escutam as vozes da água" (p.5).

O entrelaçamento entre o mundo dos vivos e o mundo dos mortos faz parte da cultura africana, sem dúvida, mas também está na base de muitas crenças do mundo ocidental, não configurando, portanto, um traço diacrítico.

No romance, o insólito também se apresenta sob a forma de transformações físicas sofridas pelas personagens. Assim como na narrativa do passado cabe a Padre Antunes passar pela mutação de raça, convertendo-se de branco em negro (COUTO, 2006, p.164), no presente, os olhos de Jesustino, goês, padrasto de Mwadia, começam a clarear e, ante o espanto da enteada, ele afirma estar mudando de raça (COUTO, 2006, p.95).

Transformação semelhante ocorrera com Constança após a morte do primeiro marido, pois quando decidiu ficar instantaneamente velha, com a força de seu desejo, começaram a surgir-lhe rugas e cabelos brancos (COUTO, 2006, p.101).

Tais mutações exigem do leitor o pacto da verossimilhança, ou seja, uma aceitação incondicional dos fatos como verdade. No plano da narrativa, Mwadia parece 
aceitar a presença do sobrenatural, do mesmo modo que sua mãe e os demais membros da família. No entanto, e contraditoriamente, há índícios no texto cuja finalidade parece ser de causar estranhamento no leitor, ou, no mínimo, despertar-lhe a atenção para o fato de que nem tudo é o que parece ser no universo ficcional.

Ai visitar as ruínas da igreja com Mestre Arcanjo, Mwadía "estranha" o fato de que não vê o reflexo do homem no espelho, mas apenas o seu: "E pensou que talvez fosse por causa das teias de aranha que cobriam quase tudo" (COUTO, 2006, p.124). Segundo Todorov, essa passagem constituiria uma instância do gênero estranho, uma vez que a personagem tenta encontrar uma explicação física para o que presencia.

O romance é construído de forma a despertar no leitor uma sensação de indefinição e incapacidade de separar o real do irreal, como, por exemplo, na passagem em que Mwadia vai à alfaiataria com o padrasto, que se recusa a entrar, dizendo que havia jurado, há muitos anos, que jamais entraria no estabelecimento novamente, "nem vivo", pois fora ali que, um dia, ele morrera (p.125). Assim como o pirotécnico Zacarias, de Murilo Rubião, Jesustino sabe-se morto.

A narrativa alimenta a incerteza sobre aquilo que encerra. A convivência entre o insólito e o cotidiano é ancorada pela passividade do narrador e da maioria das personagens, que não se questionam sobre o caráter incomum dos acontecimentos por eles vivenciados. A exceção fica por conta da vaga percepção de Mwadia, que oscila entre a aceitação e o estranhamento ante as manifestações do insólito, e da fala de Mestre Arcanjo, o barbeiro, o único que explicitamente afirma que há algo de anormal ali.

Quando Mwadia, finalmente, é confrontada com a morte do marido e descobre que fora o padrasto quem o assassinara, ela retorna a Antigamente, levando o retrato de Zero que a mãe lhe dera para que o pendurasse na parede dos ausentes.

A viagem de regresso equivale ao retorno aos labirintos da alma, pois, conforme lembra o narrador, "a viagem termina quando encerramos as nossas fronteiras interiores. Regressamos a nós, não a um lugar" (p 329).

É o marido morto quem a recebe e, dentro de si, ela carrega a certeza de que Vila Longe, assim como seus habitantes, não mais existem:

Como aceitar que Vila Longe já não tinha gente, que a maioria morreu e os restantes se foram? Como aceitar que a guerra, a doença, a fome tudo se havia cravado com garras de abutre sobre a pequena povoação? Vila Longe cansara-se de ser mapa. 
Restavam-lhe as linhas ténues da memória, com demasiadas campas e nenhuns viventes. (p. 330)

É dele também que, à guisa de consolo, ela ouve as seguintes palavras: "Custa-lhe aceitar, eu sei Mwadía. Com o tempo você vai aceitar” (p. 330). Nada mais insólito do que um morto pregando a necessidade de aceitação da morte.

A aceitação é simbolicamente representada pela parede de ausentes que ela vê no céu à noite; parede que não está no horizonte, mas em sua própria alma. É nela que pendura a foto do último ausente: Zero Madzero. Antes de dirigir-se ao rio, ela o beija "como se ele fosse apenas uma ausência adormecida" (p. 331).

Se ao longo da narrativa as manifestações do insólito parecem, por vezes, estar banalizadas, aceitas pelas personagens e exigindo do leitor a sua parte no pacto de verossimilhança, o fim do romance produz um duplo despertar: em Mwadía e no leitor.

A existência de Zero como duplo de si mesmo torna-se evidente, bem como o caráter fantasmagórico de uma Vila Longe que não mais existe, despovoada de seus habitantes, que, na mente de Mwadía, resistem ao esquecimento advindo da morte. Essa resistência se concretiza nos retratos, cujas imagens continuam a envelhecer.

A autognose de Mwadía corresponde ao fim do pacto entre texto e leitor, pois este chega ao fim do romance em busca de um significado para tudo o que leu. E é a narrativa da chegada dos americanos, com todas as suas implicações acerca da identidade, do panafricanismo e da globalização, que contém a chave de leitura do texto.

Até mesmo a crença no sobrenatural, tão cara à cultura africana, é posta em xeque. A questão da feitiçaria é tematizada em sua relação com as transformações sociais, uma vez que, graças a questões econômicas, perde a sua característica religiosa e passa a fazer parte de uma pantomima comercial. Mwadia é convocada a encenar transes, visitas de espíritos, para impressionar os americanos. Para torná-los convincentes, de dia lê os velhos documentos de D. Gonçalo, encontrados com a santa; à noite vai ao quarto dos americanos e lê os papéis do casal, além de visitar a biblioteca que o padrasto havia herdado. O efeito da encenação é imediato: "Como Casuarino previra, os americanos ficaram fascinados com a sessão de transe (...) Eis África autêntica, repetiam, deleitados" (p.236).

Assim, instaurando e subvertendo o insólito, o autor revisita suas raízes, e a intentio operis parece ser provar que a palavra é o locus de construção da identidade e 
da preservação da memória. Mia Couto opta por mostrar que compete ao homem decidir o que deve ou não ser lembrado.

Mia Couto não escreve um romance sobre africanos e para africanos, mas um texto em que a existência do insólito desafia não apenas a atmosfera mágica da cultura africana em suas raízes, como também o olhar pragmático e padronizador do mundo contemporâneo.

Se $O$ outro pé da sereia cria para si um leitor-modelo, se traz em si a intentio operis defendida por Umberto Eco, decerto não descarta níveis de inteligibilidade que refletem diferentes percepções do insólito na literatura africana: a do olhar europeu sobre a África e a do olhar africano sobre a sua própria cultura.

Afinal, temos olhos, mas "o que vemos não é o que olhamos, mas o que nosso olhar semeia no mais denso escuro" (p.316).

\section{Referências Bibliográficas:}

COUTO, Mia. O outro pé da sereia. São Paulo: Companhia das Letras, 2006.

ECO, Umberto. Obra Aberta. (8.ed.) São Paulo, SP: Perspectiva, 1991.

Lector in fabula. A cooperação interpretativa nos textos narrativos, trad. de Attílio Cancian. São Paulo: Perspectiva, 1986.

. Sobre os espelhos e outros ensaios, trad. de Beatriz Borges.Rio de Janeiro: Nova Fronteira, 1989.

The role of the reader: explorations in the semiotics of texts: Explorations in the Semiotics of Texts. Bloomington: Indiana University Press, 1979.

Interpretação e superinterpretação. São Paulo: Martins Fontes, 1997.

Os Limites da Interpretação. Lisboa: Difel, 1992.

Seis passeios pelos bosques da recepção. São Paulo, Cia das Letras, 1994.

HORTA, José da Silva. "Entre história européia e história africana, um objecto de charneira: as representações". Actas do Colóquio Construção e Ensino da História da África. Lisboa: Linopazes, 1995.

JUNOD, Henrique. Usos e costumes dos Bantus. Maputo: Imprensa Nacional de Moçambique, 1974, 1975, 2v.

MARTINS, Celina. O estorinhador Mia Couto. A poética da diversidade. Disponível em: http://www.rbleditora.com/revista/artigos/celina3.html

REGO, António da Silva. Lições de Missionologia. Lisboa: Estudos de Ciências Políticas e Sociais no. 56, Centro de Estudos Políticos e Sociais da Junta de Investigações do Ultramar, Ministério do Ultramar: 1961, pp. 296-297.

TODOROV, Tzvetan. Introdução à literatura fantástica. São Paulo: Perspectiva, 1975. 